\title{
СКОРОСТЬ СЕДИМЕНТОГЕНЕЗА В ОЗЕРЕ АРАХЛЕЙ (Центральное Забайкалье) ПО РАДИОГЕОХИМИЧЕСКИМ И ПАЛИНОЛОГИЧЕСКИМ ДАННЫМ
}

\author{
А.Б. Птицын, Г. Чу*, А.В. Дарьин**, Л.В. Замана, И.А. Калугин**, С.А. Решетова \\ Институт природных ресурсов, экологии и криологии СО РАН, 672014, Чита, ул. Недорезова, 16а, Россия \\ * Institute of Geology and Geophysics, Chinese Academy of Sciences, Beijing, China \\ ** Институт геологии и минералогии им. В.С. Соболева СО РАН, \\ 630090, Новосибирск, просп. Академика Коптюга, 3, Россия
}

\begin{abstract}
Выполнены химические, радиоизотопные, палинологические исследования донных осадков мезотрофного оз. Арахлей с целью палеоклиматических реконструкций и оценки скорости осадконакопления.

Седиментогенез, озера, донные осадки, радиоизотопия, палинология.
\end{abstract}

\section{THE RATE OF SEDIMENTATION IN LAKE ARAKHLEI (central Transbaikalia), FROM RADIOGEOCHEMICAL AND PALYNOLOGICAL DATA}

A.B. Ptitsyn, G.Chu, A.V. Dar'in, L.V. Zamana, I.A. Kalugin, and S.A. Reshetova

Chemical, radioisotopic, and palynological studies of the bottom sediments of mesotrophic Lake Arakhlei have been carried out for paleoclimatic reconstructions and estimation of the sedimentation rate.

Sediment genesis, lake, bottom sediments, radioisotope method, palynology

\section{ВВЕДЕНИЕ}

Комплексное изучение донных осадков озер разной глубины и гидрологического режима, расположенных в различных ландшафтно-климатических зонах, дает основу для разнопериодных палеоклиматических реконструкций. Сопоставление данных по разным объектам позволит в будущем выявить тенденции изменения климата в отдельных частях крупного Азиатского региона. Однако полнота исследований этих вопросов крайне неравномерна. Это связано как с большими размерами региона, так и с трудоемкостью подобных работ. Вместе с тем постепенно совместными усилиями исследователей белые пятна ликвидируются.

Так, для Прибайкалья на основе данных палинологического анализа получен детальный материал по палеогеографии в позднеледниковье и голоцене [Безрукова, 1999; Безрукова и др., 2011]. Однако подобные сведения по Центральному Забайкалью (в пределах Забайкальского края) пока недостаточны. Например, можно упомянуть работу [Виппер, Голубева, 1976], в которой рассматривается эволюция растительности западной части Забайкальского края с раннего голоцена по результатам изучения донных осадков оз. Танга. Реконструкция растительности и климата Юго-Восточного Забайкалья в среднем и позднем голоцене выполнена по результатам изучения разреза пойменных отложений р. Иля - левого притока р. Онон [Базарова и др., 2008].

Задача данной работы - на основе комплексных исследований донных осадков оз. Арахлей (Центральное Забайкалье) расширить базу данных по скорости осадконакопления и реконструкции палеоклимата.

Забайкалье характеризуется континентальным и резко-континентальным климатом с суровой зимой и довольно жарким летом. Семиаридные и засушливые субгумидные районы расположены на юге и юго-востоке Забайкалья (южнее 53-й параллели). Индекс аридности (отношение годовой суммы осадков к потенциальной эвапотранспирации) средний за многолетний период равен $0.65-0.75$, а в засушливые годы - ниже 0.65. Суммарная годовая солнечная радиация на засушливых территориях составляет 100-126 ккал/см². Годовое количество осадков составляет 200-300 мм, из которых 80-90\% выпадает летом.

\section{МЕТОДЫ ОТБОРА, ПОДГОТОВКИ И АНАЛИЗА ПРОБ ДОННЫХ ОСАДКОВ ОЗЕР}

Ненарушенные керны донных осадков извлекались с помощью стальных или пластмассовых трубок. При большей глубине водоема трубка с набором грузов крепилась к капроновому фалу и либо 
бросалась с определенной высоты, либо опускалась медленно, а затем постепенно вбивалась в грунт специальным ударником. Для отбора коротких (до 20 см) кернов использовался ящичный пробоотборник, гарантирующий получение ненарушенных верхних слоев.

Для отбора проб на изотопный, палинологический и другие виды анализов, для которых использовали отдельные образцы небольшого объема, от керна последовательно отрезались диски определенной толщины. Керн донных осадков перемещался в специальную трубку и разрезался вдоль на две половины для последующих анализов. Налажено изготовление твердых препаратов из влажного керна по известным зарубежным технологиям [Daryin et al., 2005]. Препараты пригодны для длительного хранения, изготовления шлифов для изучения на оптическом микроскопе, для рентгеновских и других современных методов микроанализа.

Для определения содержания элементов использовался метод рентгенофлуоресцентного анализа на пучках синхротронного излучения (РФА СИ) на экспериментальной станции Сибирского центра синхротронного излучения, ИЯФ СО РАН, г. Новосибирск. Набор, энергетическая калибровка и запись спектров РФА осуществлялись с помощью программы OxfordWIN-MCA, первичная обработка спектров (идентификация элементов и определение площадей пиков) проводилась программой AXI [Van Espen et al., 1986; Дарьин и др., 2013]. В результате получена непрерывная запись сигналов 25-30 параметров вдоль всего исследованного интервала колонки с заданной частотой опробования.

Для уменьшения статистического разброса, обусловленного случайными факторами, выполнялось сглаживание методом скользящего среднего по трем, четырем или пяти точкам. Для более «чистого» выделения рефлекса каждого слоя (пика) применялась процедура вычитания «фона». Под фоном понималась численная характеристика измеряемого параметра на верхней и нижней границах слоя.

Гидрогеохимические исследования выполнены в ИПРЭК СО РАН по общепринятым методикам (аналитики С.В. Борзенко, Т.Е. Хвостова и Т.Г. Смирнова). Концентрации кальция и магния определялись методом атомной абсорбции в аргон-ацетиленовом пламени на спектрофотометре SOLAAR 6M. Для определения натрия и калия использован пламенно-эмиссионный метод. Потенциометрически с применением ионселективных электродов определялись $\mathrm{pH}$ и $\mathrm{Cl}^{-}$. Титрование осуществлялось для определения содержания $\mathrm{CO}_{3}^{2-}, \mathrm{HCO}_{3}^{-}$. Сульфат-ион определялся турбидиметрическим методом в виде сернокислого бария.

Радиоизотопный анализ на ${ }^{14} \mathrm{C}$ выполнялся в радиокарбоновой лаборатории университета Адама Мицкевича, г. Познань [Птицын и др., 2010]. Этот метод широко используется для датировки климатических событий голоцена [Агатова и др., 2012].

Пробы для палинологического анализа отобраны с шагом в 1см. Подготовка проб проведена по стандартной методике [Покровская, 1950]. Микроскопический анализ выполнен с помощью биологического микроскопа ZeissAxiolab при 400-630-кратном увеличении. При расчете процентного содержания индивидуальных таксонов в спектрах за 100 \% принималась сумма пыльцы древесных растений. Полная палинологическая диаграмма ранее была опубликована А.Б. Птицыным с соавторами [2010]. В данной работе она представлена для древесной, кустарниковой и травянистой частей спектров с добавлением пыльцевых индексов степь/лес.

\section{КРАТКАЯ ХАРАКТЕРИСТИКА ОБЪЕКТА ИССЛЕДОВАНИЙ}

Озеро Арахлей расположено на юге Витимского плоскогорья в днище Беклемишевской межгорной впадины на высоте 965 м над ур. м. Площадь его водного зеркала 59 км², наибольшая глубина 17 м, площадь водосбора 256 км² [Ивано-Арахлейский..., 2002]. С северо-запада впадина ограничена Осиновским (отроги хр. Цаган-Хуртэй), с юго-запада - Яблоновым горными хребтами. Водоразделы подняты над урезом воды в озере на $300-450$ м. Озеро входит в систему Ивано-Арахлейских озер, насчитывающей 6 относительно крупных и около 20 мелких озер, в основном вытянутых цепочкой по оси впадины. Орографическая особенность оз. Арахлей - положение его на границе водосборного бассейна оз. Байкал, проходящей по узкому перешейку с расположенным восточнее озером Иван, входящем в водосбор р. Лена. Такая орография определяет отсутствие протяженных впадающих в оз. Арахлей притоков, наиболее крупный из которых р. Грязнуха имеет длину всего 9.8 км, а также особенности формирования водного баланса озера и осадконакопления в нем.

Климат территории резко-континентальный, умеренно-влажный, с большими суточными и годовыми колебаниями температуры и неравномерным распределением осадков по сезонам года. Среднегодовая температура воздуха по данным расположенной у озера метеостанции составляет $-3.2{ }^{\circ} \mathrm{C}$, средняя температура января $-25.9^{\circ} \mathrm{C}$, июля $15.3^{\circ} \mathrm{C}$. Годовая сумма осадков $350-380$ мм, из них 80-90\% выпадает в теплый период года (май-сентябрь). Индекс континентальности климата, по С.П. Хромову, равен 0.89 , радиационный индекс сухости, по М.И. Будыко, 1.0-1.5.

Современная растительность в связи с горно-котловинным рельефом и наличием озер, создающих микроклиматические условия, представлена, несмотря на сравнительно небольшую территорию, лесны- 
ми, степными, луговыми, лугово-болотными и кустарниковыми формациями. Среди лесов доминируют лиственничники, подчиненным развитием пользуются сосняки, редко встречаются березовые леса. В составе лиственничных лесов отмечается ель сибирская. Степи луговые, настоящие степи для территории не характерны. Лугово-болотные группировки занимают днища падей, часто заболоченные, чему способствует развитие многолетней мерзлоты.

В приходных статьях многолетнего водного баланса оз. Арахлей около 52 \% приходится на осадки на его водную поверхность, до 20 \% составляет приток талых, остальное - дождевых вод. Расходные статьи почти на 80 \% представлены испарением с водного зеркала, сток не превышает $20 \%$. Коэффициент условного водообмена озера равен 0.055 , время полной смены воды около 18 лет. Сток в озеро в основном существует в период снеготаяния (май) и основных летних осадков (июль-август). Зимой водотоки перемерзают. Озеро более полугода (190-220 сут.) покрыто льдом. Средняя многолетняя амплитуда колебания уровня воды в озере за год равна 0.30 м, максимальная годовая за период с 1961 г. составила $0.86 \mathrm{м}$, а общая - $2.19 \mathrm{м}$.

Трофический тип озера мезотрофный. Вода озера гидрокарбонатная, в основном трехкомпонентная по катионам с преобладанием кальция и мольными отношениями $\mathrm{Ca} / \mathrm{Mg}=1.1-1.8$. Минерализация ее колеблется в пределах 160-185 мг/л, проявляя слабые разнонаправленные тренды изменения по глубине в зависимости от образования и таяния льда, выпадения осадков и испарения, а также биологических процессов, в особенности фотосинтеза и деструкции органического вещества, продуцируемого биогеоценозами озера. С этими процессами связаны колебания значений $\mathrm{pH}$, которые по данным наблюдений за последние три года изменялись в интервале 7.2-8.7. В придонных слоях в отдельные сроки отмечается понижение величины $\mathrm{pH}$ как в центре, так и в прибрежье озера, что вызвано минерализацией органического вещества донных осадков с образованием $\mathrm{CO}_{2}$. В целом внутриводоемные гидробиологические процессы не играют столь значимой роли в формировании гидрохимических характеристик озера, как в случае соленых озер Забайкалья, для которых эти процессы - одни из главных в трансформациях химического состава озерных вод [Замана, 2009]. Основным источником поступления химических компонентов в оз. Арахлей являются стекающие в него поверхностные воды.

Терригенный материал поступает с поверхностным стоком, судя по всему, в ограниченных масштабах, что определяется не только невысоким модулем стока, но и устойчивостью к выветриванию доминирующих на водосборе магматических и метаморфических пород (гранитоиды, гнейсы, эффузивы кислого и основного составов). Водно-эрозионные процессы проявлены незначительно и практически ограничиваются руслами водотоков, большей частью заросших. Седиментация твердого стока и взвеси, поступающей в результате береговых процессов, в подавляющей массе происходит в пределах литорали озера. Эоловый вклад в осадки озера также незначителен, за исключением редких пыльных бурь, приходящих из Монголии.

\section{ПОЛУЧЕННЫЕ РЕЗУЛЬТАТЫ}

Донные осадки отбирались в наиболее глубоководной части оз. Арахлей (глубина около 15 м) в окрестностях точки с координатами $52^{\circ} 13^{\prime}$ с.ш., $112^{\circ} 53^{\prime}$ в.д. Всего отобрано восемь кернов: три 20 -сантиметровых - ящиком-пробоотборником, три мощностью 60-80 см и два мощностью 160-180 см с использованием гравитационных трубок. По составу это близкие к сапропелю карбонатсодержащие органогенные осадки с высокой влажностью (88-90\%), примесью алевритовых обломочных частиц, представленных кварцем, слюдой, полевым шпатом.

Термодинамические расчеты показали, что при $\mathrm{pH}>8$ вода озера в периоды прогрева насыщена по карбонатам кальция и доломиту, что определяет возможность их седиментации, хотя, исходя из степени насыщения (в основном не более 1.0), и в незначительных масштабах. По магнезиальным кальцитам, согласно расчетам по приведенным в работе [Гаськова и др., 2011] величинам свободных энергий Гиббса, термодинамическое равновесие не достигается. Частично гидрогенными могут быть кварц и некоторые слоистые алюмосиликаты, с которым вода озера находится в равновесии. Гидробиологические процессы обеспечивают накопление в донных осадках органического вещества и, следовательно, преимущественно сапропелевый тип седиментации.

Таким образом, осадконакопление в озере определяется главным образом биогенными процессами и, следовательно, связано с колебаниями биопродуктивности, которая, в свою очередь, зависит от положения уровня озера, колеблющегося в зависимости от водности года. Иначе говоря, первопричиной колебаний скорости осадконакопления следует признать климатические факторы, показателями которых являются палинологические данные.

В табл. 1 приведены содержания некоторых химических элементов в верхнем слое керна донных осадков. Из большого числа проанализированных элементов выбраны лишь те, вариации содержаний которых наиболее существенны и, соответственно, могут дать информацию о смене обстановки осадко- 
Содержание химических элементов в ненарушенном керне донных осадков оз. Арахлей (г/т) в зависимости от глубины (мм)

\begin{tabular}{|c|c|c|c|c|c|c|c|}
\hline Глубина & $\mathrm{Fe}$ & $\mathrm{Cu}$ & $\mathrm{Zn}$ & $\mathrm{Sr}$ & $\mathrm{Ba}$ & $\mathrm{La}$ & $\mathrm{Br}$ \\
\hline 0.5 & 130984.0 & 104.4 & 109.1 & 143.7 & 361.7 & 14.7 & 87.9 \\
\hline 2.5 & 118709.5 & 91.3 & 94.7 & 148.6 & 386.5 & 13.1 & 81.6 \\
\hline 5.0 & 136827.5 & 87.7 & 111.3 & 163.8 & 526.9 & 15.4 & 79.6 \\
\hline 7.5 & 133176.7 & 100.5 & 113.2 & 163.0 & 496.0 & 22.4 & 92.9 \\
\hline 10.0 & 130525.5 & 96.9 & 117.7 & 153.4 & 472.8 & 23.4 & 84.2 \\
\hline 12.5 & 134663.0 & 108.2 & 115.7 & 150.4 & 447.4 & 27.7 & 81.7 \\
\hline 15.0 & 133567.7 & 93.4 & 115.9 & 151.4 & 468.2 & 28.0 & 85.5 \\
\hline 17.5 & 135148.1 & 95.4 & 118.4 & 168.0 & 464.6 & 21.1 & 77.8 \\
\hline 20.0 & 133331.8 & 93.6 & 113.0 & 160.5 & 502.0 & 23.9 & 84.8 \\
\hline 22.5 & 136874.3 & 101.2 & 99.6 & 152.8 & 506.9 & 23.7 & 82.7 \\
\hline 25.0 & 138196.5 & 86.1 & 108.9 & 153.7 & 468.9 & 24.3 & 85.1 \\
\hline 27.5 & 135113.8 & 91.9 & 142.1 & 163.4 & 474.5 & 25.1 & 90.6 \\
\hline 30.0 & 131586.2 & 111.4 & 105.8 & 155.8 & 530.9 & 22.4 & 82.6 \\
\hline 32.5 & 129166.7 & 95.9 & 134.7 & 159.0 & 519.4 & 25.4 & 88.7 \\
\hline 35.0 & 133013.3 & 96.0 & 116.5 & 160.9 & 484.6 & 21.8 & 99.9 \\
\hline 37.5 & 130252.9 & 84.3 & 110.9 & 163.5 & 467.9 & 27.6 & 84.1 \\
\hline 40.0 & 132741.8 & 88.3 & 129.9 & 159.3 & 474.1 & 22.2 & 83.7 \\
\hline 42.5 & 137780.6 & 110.3 & 113.5 & 157.1 & 509.3 & 29.3 & 88.8 \\
\hline 45.0 & 141413.9 & 106.5 & 110.2 & 150.7 & 479.9 & 20.9 & 81.1 \\
\hline 47.5 & 153965.9 & 96.5 & 105.6 & 152.9 & 484.5 & 23.1 & 82.3 \\
\hline 50.0 & 129129.8 & 104.8 & 122.6 & 150.2 & 461.3 & 18.4 & 84.8 \\
\hline 52.5 & 125214.3 & 103.0 & 127.9 & 152.6 & 458.8 & 22.0 & 82.2 \\
\hline 55.0 & 126335.4 & 88.7 & 118.4 & 156.4 & 532.0 & 21.0 & 81.7 \\
\hline 57.5 & 125691.0 & 109.4 & 108.7 & 144.8 & 475.6 & 24.2 & 85.8 \\
\hline 60.0 & 129634.8 & 97.1 & 116.3 & 152.5 & 458.2 & 23.1 & 88.9 \\
\hline 62.5 & 125053.4 & 103.5 & 127.5 & 165.8 & 494.3 & 27.6 & 87.5 \\
\hline 65.0 & 125948.9 & 110.0 & 116.7 & 153.9 & 486.1 & 23.3 & 85.7 \\
\hline 67.5 & 136441.4 & 118.6 & 108.1 & 161.1 & 463.1 & 21.4 & 84.6 \\
\hline 70.0 & 138481.4 & 108.1 & 124.4 & 153.7 & 475.8 & 25.6 & 79.9 \\
\hline 72.5 & 126006.6 & 101.8 & 102.1 & 171.2 & 509.1 & 21.3 & 80.1 \\
\hline 75.0 & 128651.8 & 104.2 & 120.0 & 159.9 & 473.6 & 23.3 & 86.2 \\
\hline 77.5 & 132608.7 & 121.5 & 112.5 & 152.4 & 502.7 & 24.8 & 76.6 \\
\hline 80.0 & 140883.4 & 97.8 & 112.6 & 179.8 & 505.6 & 23.8 & 83.4 \\
\hline 82.5 & 156872.4 & 82.7 & 107.7 & 153.4 & 498.8 & 25.2 & 79.3 \\
\hline 85.0 & 153241.4 & 102.6 & 114.4 & 152.5 & 464.2 & 25.3 & 81.9 \\
\hline 87.5 & 135257.3 & 98.3 & 125.0 & 150.6 & 439.1 & 20.0 & 82.6 \\
\hline 90.0 & 131148.5 & 91.7 & 111.0 & 154.5 & 447.8 & 24.2 & 85.9 \\
\hline 92.5 & 124976.8 & 87.3 & 128.2 & 148.5 & 486.5 & 26.8 & 76.6 \\
\hline 95.0 & 128.951 .9 & 103.2 & 111.3 & 148.4 & 444.2 & 29.3 & 82.4 \\
\hline 97.5 & 129665.9 & 119.1 & 168.8 & 156.6 & 418.4 & 27.7 & 95.8 \\
\hline 100.0 & 130221.7 & 103.3 & 139.6 & 150.9 & 459.2 & 21.5 & 92.7 \\
\hline
\end{tabular}

накопления. Из-за большого объема выборки в таблице приведены данные с шагом 2.5 мм и только в верхнем 10-сантиметровом слое, хотя авторы располагают информацией о содержаниях элементов в керне с шагом 0.5 мм.

Как видно из таблицы, наиболее информативными элементами являются железо и барий (рис. 1). Жирные линии (см. рис. 1) получены путем обработки первичной информации (тонкие линии) по описанной выше методике. Между содержаниями железа и бария нет четкой корреляции (рис. 2), хотя некоторая тенденция просматривается - они колеблются в противофазе. Сравнивая части $a$ и $\sigma$ рис. 1 , 
Таблица 2. Результаты ${ }^{14}$ С датирования отложений оз. Арахлей и скорость аккумуляции отложений

\begin{tabular}{c|c|c}
\hline Глубина от поверхности керна, см & Значение калиброванного возраста, годы & Скорость аккумуляции, мм/год \\
\hline 14.5 & 2353.5 & 0.061 \\
50.0 & 5087.0 & 0.098 \\
144.0 & 13009.5 & 0.111
\end{tabular}

можно выделить две возможные границы смены обстановки осадконакопления: около 120 мм и около 200 мM.

В целом группировка элементов и тенденции распределения их по разрезу другие, чем в осадках терригенного глинистого типа, из-за высокого содержании органического вещества.

Скорости осадконакопления в оз. Арахлей (табл. 2), рассчитанные исходя из данных датирования отложений по органическому веществу методом ускоренной масс-спектрометрии [Решетова и др., 2013], показывают, что верхние 19 см осадка накапливались примерно в течение последних 3000 лет, частично включая суббореальную и охватывая субатлантическую стадии голоцена [Roberts, 1998].

На пыльцевой диаграмме разреза донных осадков оз. Арахлей (рис. 3) выделены две палинозоны, описание которых приводится снизу вверх.

Палинозона 2 (19-10 см) - Larix-Pinus sylvestris-Abies-Picea. В спектрах доминирует пыльца сосны. Значительно (до 5 \%) содержание пыльцы лиственницы.

Палинозона 1 (10-0 см) - Larix — Betula alba-type-Artemisia. В составе спектров обильна пыльца мелколиственных пород - берез обеих секций. Количество пыльцы лиственницы не превышает $1-2 \%$. В группе пыльцы травянистых растений доминирует пыльца полыни.

Палинологические данные зоны 2 позволяют реконструировать светлохвойные леса из сосны и лиственницы с незначительным участием темнохвойных пород из ели и пихты, которые были распространены в Беклемишевской котловине в период примерно от 3000 до 1500 л.н. Такая ситуация была характерна для территории Алханайского горного массива юго-восточной части Забайкалья [Базарова и др., 2008], где в среднем и позднем голоцене также господствовали лесные формации с преобладанием светлохвойной тайги.

В интервале 1600 - 1500 л.н. в Беклемишевской котловине произошло сокращение площадей, занятых сосной и лиственницей, с практически полным исчезновением из их состава темнохвойных представителей, на что указывают палинологические спектры зоны 1. На территории стали расселяться березовые леса. По берегам озера распространялись заросли ерниковых ассоциаций из березки кустарниковой и ольховника. Значительно расширились площади, занятые сухостепными маревопо-
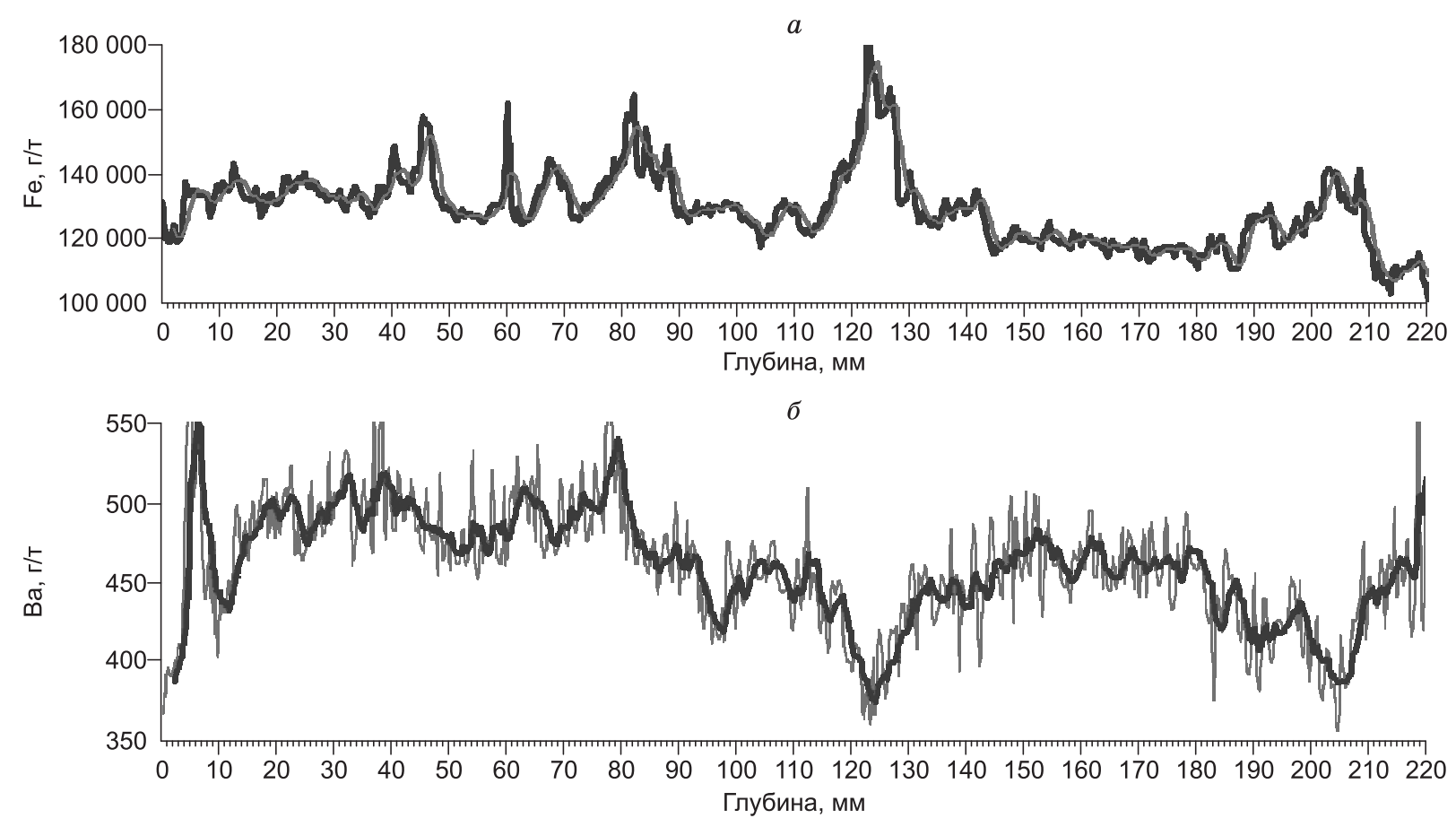

Рис. 1. Изменение содержания железа (а) и бария (б) в донных осадках с глубиной. 


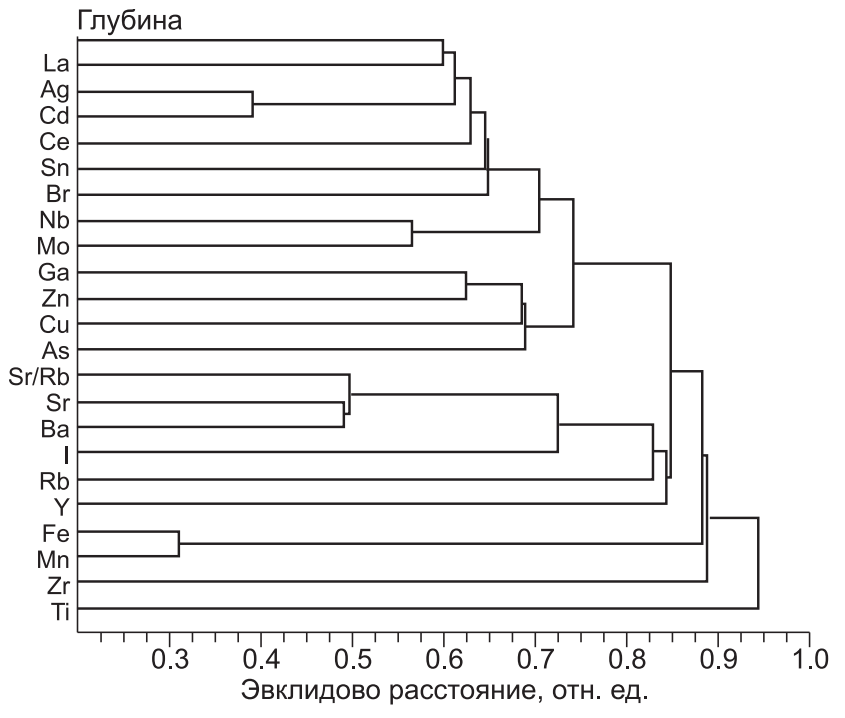

Рис. 2. Дендрограмма корреляционных связей содержаний элементов и глубины (мм) по керну в донных осадках.

лынными ассоциациями, о чем на палинологической диаграмме свидетельствует увеличение значений индексов степь/лес. На территории Алханайского нагорья в конце субатлантического периода также отмечено сокращение сосновых лесов и установлены следы значительного расширения площадей степных сообществ.

Граница в осадках на глубине около 109 см, указывающая на смену доминант в составе растительности Беклемишевской котловины и отражающая существенные изменения природной среды, выделяется по содержанию воды и индикаторных элементов (Ва и др.).

Средняя скорость осадконакопления в оз. Арахлей, рассчитанная по радиоуглеродным датировкам по трем пробам с разной глубины, составила $0.061-0.111$ мм/год, что заметно выше, чем в расположенном примерно в 250 км южнее оз. Зун-Соктуй, где величина ее на возрастном интервале в 5670 лет изменяется в пределах $0.047-0.050$ мм/год [Базарова и др., 2011$].$

Для сравнения скорость седиментации в оз. Зун-Торей (Юго-Восточное Забайкалье), рассчитанная по содержанию техногенного радиоизотопа ${ }^{137} \mathrm{Cs}$ по разным реперам, составила $3.0 \pm 0.3 \mathrm{mм} /$ год [Замана и др., 2011], а в оз. Сихайлонгван (Северо-Восточный Китай) в среднем равнялась 0.5 мм/год при вариациях по годам от 0.3 до 0.7 мм/год [Chu et al., 2005].

Озеро Зун-Торей является одним из бессточных озер Забайкалья, расположенных на юге региона. Особенностью этих озер являются периодические понижения-повышения уровня воды вплоть до полного высыхания в наиболее засушливые периоды. Площадь оз. Зун-Торей в годы повышенной водности до 300 км², наибольшая глубина в периоды максимального наполнения около 7 м. Оз. Сихайлонгван расположено на северо-востоке Китая в районе, сложенном щелочными базальтами. Площадь озера 0.39 км², максимальная глубина 50 м. Озеро покрыто льдом с конца ноября до начала апреля. Климат района сильно зависит от восточно-азиатских муссонов. Среднегодовая температура воздуха около $4{ }^{\circ} \mathrm{C}$. Весной холодные ветры из Сибири иногда сопровождаются пыльными бурями. Пыльные бури хорошо документированы в Китае и других восточно-азиатских странах с 1150 г. и, следовательно, могут служить временными реперами.

В крупных глубоководных озерах скорости седиментации также заметно различаются. Так, в оз. Телецкое по изотопным измерениям на временной интервал 3000 лет осадки накапливаются со ско-

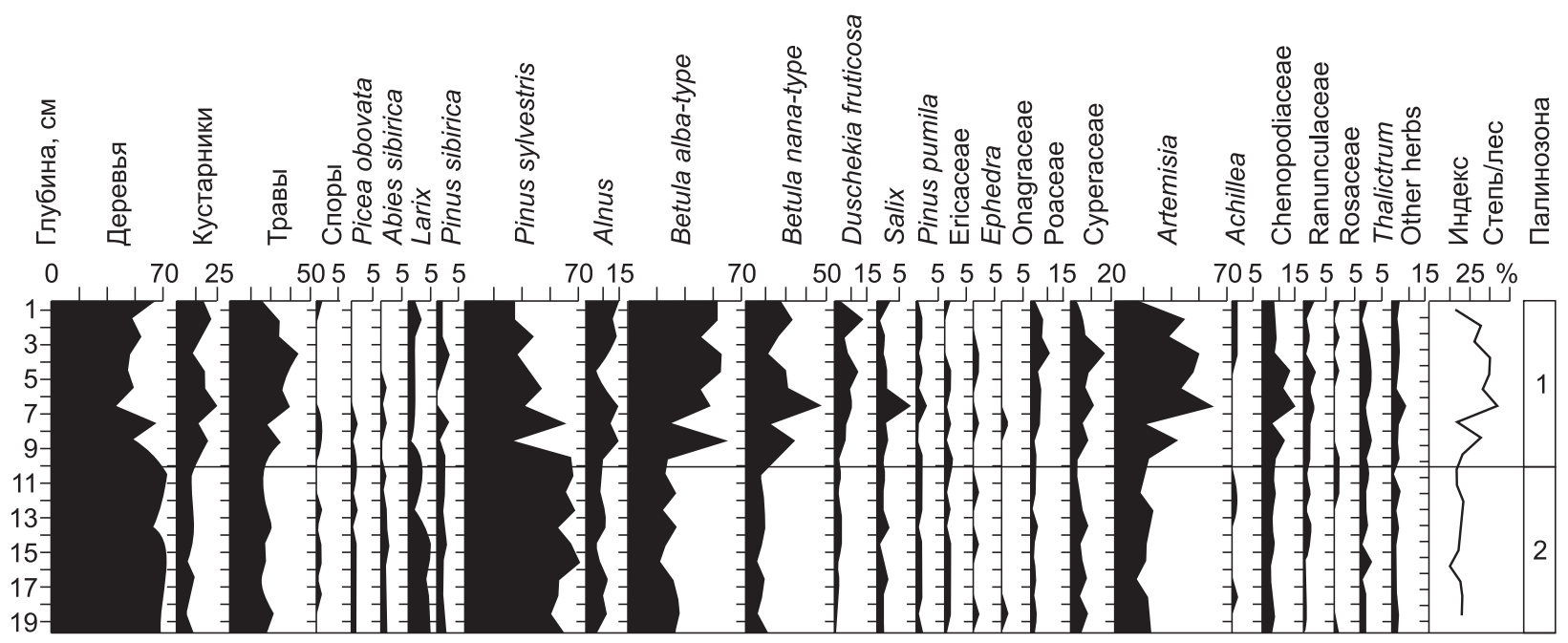

Рис. 3. Палинологическая диаграмма донных осадков оз. Арахлей. 
ростью 0.4 мм в год [Калугин и др., 2009], на Академическом хребте в оз. Байкал темпы седиментации определены в 0.04 мм [Коллектив..., 2000], а в оз. Хубсугул - близкая в таковой в оз. Арахлей 0.06 мм в год [Коллектив..., 2007].

Таким образом, по осадкам оз. Арахлей можно изучать динамику климата за период более 15000 лет, донные осадки оз. Зун-Торей следует использовать для детальных палеореконструкций за последние 80-90 лет, оз. Сихайлонгван занимает промежуточное положение. Более длинные палеоклиматические ряды дают исследования донных осадков глубоководных озер (Байкал, Телецкое). Следовательно, для получения достаточно полной и объективной картины климатических изменений в Азиатском регионе необходимо комплексное изучение донных осадков и процессов осадконакопления в озерах различной глубины, трофности, солености, техногенной нагрузки и т.д.

\section{ВЫВОдЫ}

Палинологическое и геохимическое исследование донных осадков оз. Арахлей не противоречит низким значениям скорости осадконакопления в озере, которые можно объяснить несколькими причинами.

Во-первых, слабая расчлененность и незначительные отметки высот окружающего рельефа Беклемишевской впадины снижают денудационный потенциал, в связи с чем продукты разрушения коренного субстрата расходуются на формирование сплошного, но маломощного покрова элювиальных и делювиальных отложений на водоразделах и склонах [Ерхов, 1972].

Во-вторых, характерной особенностью группы Ивано-Арахлейских озер является то, что они расположены на глобальном водоразделе двух противоположных направлений стока рек в Северный Ледовитый и Тихий океаны и находятся в стороне от хорошо развитой действующей эрозионной сети [Флоренсов, 1960]. Базис эрозии рек Ингода, Чита, Конда и Хилок существенно ниже базиса эрозии рек Беклемишевской котловины. При этом из шести относительно крупных озер Ивано-Арахлейской системы оз. Арахлей занимает наибольшее высотное положение.

В-третьих, подавляющее число водотоков Беклемишевской котловины (86 \%) представлено ручьями, длина которых не более 10 км, а уклоны продольного профиля не превышают 0.007. В оз. Арахлей впадает одна р. Грязнуха. Ее протяженность составляет 9.8 км, а площадь водосбора - 12.4 км². $^{2}$

$\mathrm{B}$ соответствии с характером водосбора и условиями питания уровенный режим оз. Арахлей очень устойчив, дождевой сток вызывает повышение уровня озера всего на 10-20 см. Существенным является и то, что в расходной части водного баланса преобладает испарение и только около $30 \%$ составляет жидкий сток, что значительно снижает энергию водного потока.

Все это характеризует низкие темпы приноса терригенного материала в озеро, в связи с чем закономерным является преобладание в донных осадках озера мелкодисперсных илов с выраженной стратификацией слоев и высоким содержанием органического вещества.

Работа выполнена при поддержке РФФИ и ГФЕН (гранты 07-05-92103, 07-04-92108).

\section{ЛИТЕРАТУРА}

Агатова А.Р., Назаров А.Н., Непоп Р.К., Орлова Л.А. Радиоуглеродная хронология гляциальных и климатических событий голоцена Юго-Восточного Алтая (Центральная Азия) // Геология и геофизика, 2012, т. 53 (6), с. $712-737$.

Базарова В.Б., Мохова Л.М., Климин М.А., Орлова Л.А., Базаров К.Ю. Климатические изменения и обстановки осадконакопления в среднем-позднем голоцене в Юго-Восточном Забайкалье (на примере изучения поймы р. Иля) // Геология и геофизика, 2008, т. 49 (12), с. 1294-1303.

Базарова В.Б., Гребенникова Т.А., Мохова Л.М., Орлова Л.А. Особенности озерного осадконакопления в степной зоне Юго-Восточного Забайкалья в голоцене (на примере отложений оз. Зун-Соктуй) // Геология и геофизика, 2011, т. 52 (3), с. 426- 438.

Безрукова Е.В. Палеогеография Прибайкалья и Забайкалья в позднеледниковье и голоцене. Новосибирск, Наука, 1999, 128 с.

Безрукова Е.В., Тарасов П.Е., Кулагина Н.В., Абзаева А.А., Летунова П.П., Кострова С.С. Палинологическое исследование донных отложений озера Котокель (район озера Байкал) // Геология и геофизика, 2011, т. 52 (4), с. 586-595.

Виппер П.Б., Голубева Л.В. К истории растительности Юго-Западного Забайкалья в голоцене // Бюл. Комиссии по изучению четвертичного периода, 1976, т. 45, с. 45-55.

Гаськова О.Л., Солотчина Э.П., Склярова О.А. Реконструкция эволюции состава растворов по данным осадочной летописи соленых озер Приольхонья // Геология и геофизика, 2011, т. 52 (5), с. $704-$ 711. 
Дарьин А.В., Калугин И.А., Ракшун Я.В. Сканирующий рентгеноспектральный микроанализ образцов донных осадков с использованием синхротронного излучения из накопителя ВЭПП-3 ИЯФ СО РАН // Изв. РАН, Серия физическая, 2013, т. 77, № 2, с. 204-206.

Ерхов В.Ф. Геологическая карта СССР м-ба 1:200 000. Серия Западно-Забайкальская. Лист N-49XXXV. Объяснительная записка. Л., Ленинградская картфабрика, 1972, 82 с.

Замана Л.В. Формирование и трансформация химического состава вод минеральных озер (на примере Забайкалья) // ДАН, 2009, т. 428, № 3, с. 382-385.

Замана Л.В., Птицын А.Б., Гуосянь Чу, Решетова С.А., Дарьин А.В., Калугин И.А. Оценка скорости современного осадкообразования в озере Зун-Торей (Восточное Забайкалье) по ${ }^{137} \mathrm{Cs} / /$ ДАН, 2011, т. 437, № 3, с. 370-374.

Ивано-Арахлейский заказник: природно-ресурсный потенциал территории / Ред. В.П. Горлачев. Чита, Поиск, 2002, 232 с.

Калугин И.А., Дарьин А.В., Бабич В.В. 3000-летняя реконструкция среднегодовых температур Алтайского региона по литолого-геохимическим индикаторам донных осадков оз. Телецкое // ДАН, 2009 , т. 426, № 4, с. $520-522$.

Коллектив участников проекта «Байкал-бурение». Позднекайнозойская палеоклиматическая запись в осадках озера Байкал (по результатам исследований 600-метрового керна глубокого бурения) // Геология и геофизика, 2000, т. 41 (1), с. 3-32.

Коллектив участников проекта «Хубсугул-бурение». Строение донных осадков озера Хубсугул: его связь с геологическими и климатическими факторами // Геология и геофизика, 2007, т. 48 (11), с. $1117-1143$.

Покровская И.М. Пыльцевой анализ. Л., Госгеолиздат, 1950, 570 с.

Птицын А.Б., Решетова С.А., Бабич В.В., Дарьин А.В., Овчинников Д.В., Паниззо В., Мыглан В.С. Хронология палеоклимата и тенденции аридизации в Забайкалье за последние 1900 лет // География и природные ресурсы, 2010, № 2, с. 85-89.

Решетова С.А., Безрукова Е.В., Паниззо В., Хендерсон Э., Птицын А.Б., Дарьин А.В., Калугин И.А. Растительность Центрального Забайкалья в позднеледниковье и голоцене // География и природные ресурсы, 2013, № 2, с. 110-117. $380 \mathrm{c}$.

Флоренсов Н.А. Мезозойские и кайнозойские впадины Прибайкалья. М., Изд-во АН СССР, 1960,

Chu G.Q., Liu J.Q., Schettler G., Li J.Y., Sun Q., Gu Z.Y., Lu H.Y., Liu Q., Liu T.S. Sediment fluxes and varve formation in Sihailongwan, a maar lake from northeastern China // J. Paleolimnology, 2005, v. 34, p. $311-324$.

Daryin A.V., Kalugin I.A., Maksimova N.V., Smolyaninova L.G., Zolotarev K.V. Use of a scanning XRF analysis on SR beams from VEPP-3 storage ring for research of core bottom sediments from Teletskoe Lake with the purpose of high resolution quantitative reconstruction of last millennium paleoclimate // Nuclear Instruments and Methods in Physics Research, A 543, 2005, p. 255-258.

Roberts N. The Holocene: an environmental history. Blackwell, Oxford, 2nd edition. 1998, 315 p.

Van Espen P., Janssens K., Nobels J. AXIL PC, software for the analysis of complex X-ray spectra // Chemometrics and Intelligent Laboratory Systems, 1986, v. 1, № 1, p. 109-114. 